J. Dairy Sci. 102:4755-4756

https://doi.org/10.3168/jds.2019-102-5-4755

() American Dairy Science Association ${ }^{\circledR}, 2019$.

\title{
Corrigendum to "Infection dynamics across the dry period using Dairy Herd Improvement somatic cell count data and its effect on cow performance in the subsequent lactation" (J. Dairy Sci. 102:640-651)
}

\section{Z. Lipkens, S. Piepers, J. Verbeke, and S. De Vliegher}

In the abstract on page 640, the tenth sentence should be modified as follows (changes in bold): "Cows that cured from an IMI present at dry-off and cows with a chronic IMI across the dry period were more likely to develop clinical mastitis (hazard ratio) $=\mathbf{2 . 2 3}$ and $\mathbf{3 . 5 6} ; 95 \%$ confidence interval $=\mathbf{1 . 2 9}-\mathbf{3 . 8 5}$ and $\mathbf{1 . 8 3}-\mathbf{6 . 9 3}$, respectively) ..."

In the Results section, under subsection CM and Culling (page 645), the third sentence should read as follows (changes in bold): "The hazard of CM was significantly higher in cows with cured and chronic IMI compared with healthy cows (hazard ratio $=\mathbf{2 . 2 3}$ and $\mathbf{3 . 5 6} ; 95 \% \mathrm{CI}=\mathbf{1 . 2 9}-\mathbf{3 . 8 5}$ and $\mathbf{1 . 8 3}-\mathbf{6 . 9 3}$, respectively; Table 3 and Figure 4)." The revised Table 3 and Figure 4 are shown below.

The authors regret the errors.

Table 3. Final shared frailty survival models describing the association between infection dynamics across the dry period and the hazard of developing clinical mastitis in the subsequent lactation

\begin{tabular}{lrccccc}
\hline Predictor variable & $\mathrm{n}$ & $\beta^{1}$ & $\mathrm{SE}$ & $\mathrm{HR}^{2}$ & $95 \% \mathrm{CI} \mathrm{HR} \mathrm{H}^{2}$ & $P$-value \\
\hline Infection dynamics $^{3}$ & & & & & & $<0.01^{4}$ \\
$\quad$ Healthy & 397 & Referent & & & & \\
New IMI & 52 & 0.58 & 0.41 & 1.78 & $0.80-3.99$ & \\
Cured IMI & 162 & 0.80 & 0.28 & 2.23 & $1.29-3.85$ & \\
Chronic IMI & 75 & 1.27 & 0.34 & 3.56 & $1.83-6.93$ & \\
\hline
\end{tabular}

${ }^{1}$ Regression coefficient.

${ }^{2}$ Hazard ratio and $95 \%$ CI of $\mathrm{HR}$.

${ }^{3}$ Healthy = test-day SCC $<200,000$ cells $/ \mathrm{mL}$ before dry-off and after calving; new IMI = test-day SCC $<200,000$ cells $/ \mathrm{mL}$ before dry-off and $>200,000$ cells $/ \mathrm{mL}$ after calving; cured IMI $=$ test-day $\mathrm{SCC}>200,000$ cells/mL before dry-off and $<200,000$ cells/mL after calving; and chronic IMI $=$ test-day SCC $\geq 200,000$ cells/ $\mathrm{mL}$ before dry-off and after calving.

${ }^{4}$ Overall $P$-value of the fixed effect. 


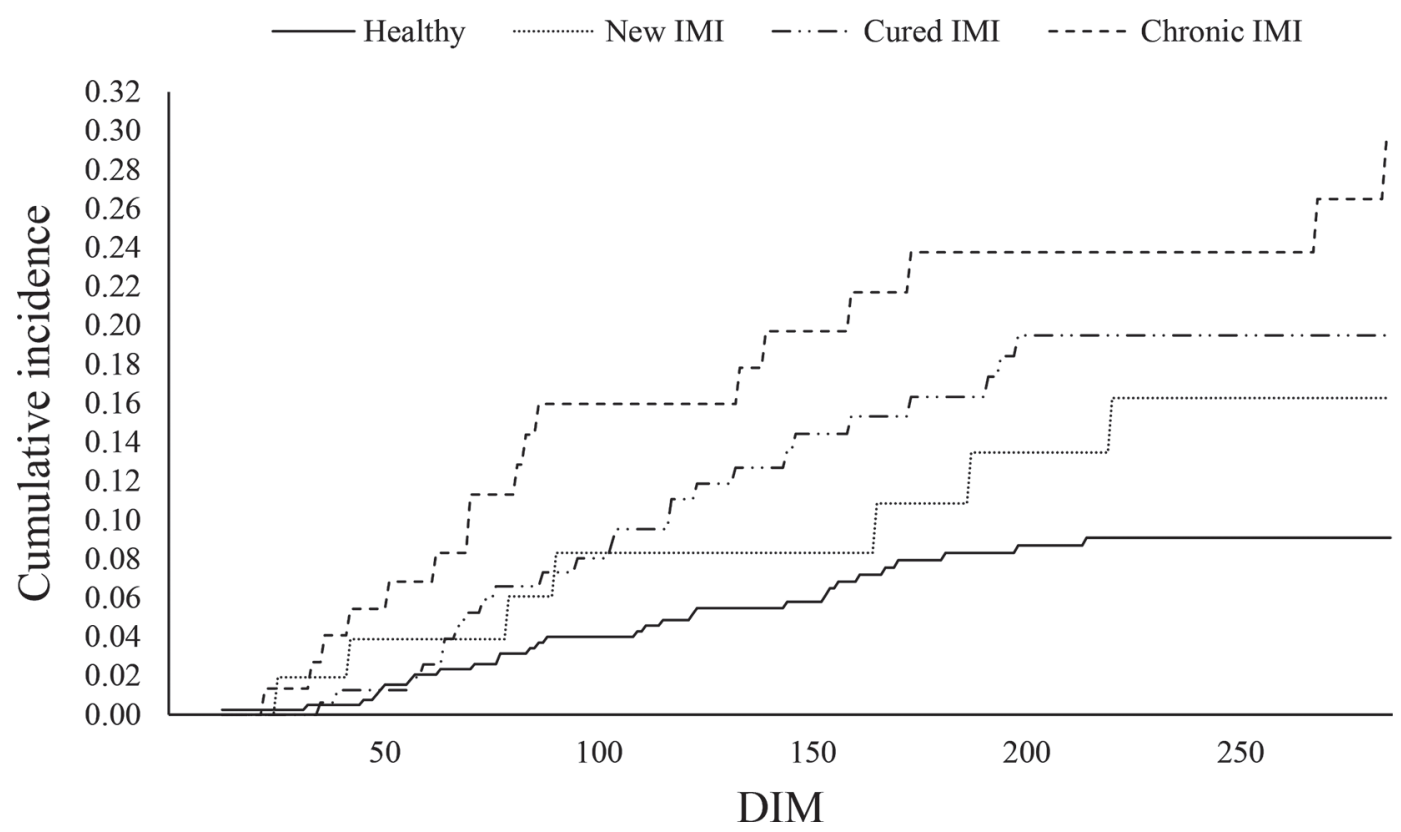

Figure 4. Kaplan-Meier graph showing the association between infection dynamics across the dry period and the hazard of developing clinical mastitis in the subsequent lactation, from 12 (after the first post-calving DHI record) to 285 DIM. Cows were considered healthy (test-day SCC $<200,000$ cells $/ \mathrm{mL}$ before and after the dry period), newly infected (new IMI; test-day SCC $<200,000$ cells/mL before the dry-off and $\geq 200,000$ cells/mL after calving), cured (from an existing IMI; test-day SCC $>200,000$ cells/mL before dry-off and $<200,000$ cells $/ \mathrm{mL}$ after calving), or chronically infected (chronic IMI; test-day SCC $\geq 200,000$ cells/mL before and after the dry period).

\section{REFERENCES}

Lipkens, Z., S. Piepers, J. Verbeke, and S. De Vliegher. 2019. Infection dynamics across the dry period using Dairy Herd Improvement somatic cell count data and its effect on cow performance in the subsequent lactation. J. Dairy Sci. 102(1):640-651. https://doi.org/10.3168/jds $.2018-15130$. 